\title{
The Politics of Law in Tackling Human Smuggling
}

\author{
Fauzhan Akbar Fhazmie Basha ${ }^{1}$, Evita Isretno Israhadi ${ }^{2}$ \\ Borobudur University, Jakarta, Indonesia ${ }^{1,2}$ \\ \{fauzhanunboro@gmail.com¹, evita_isretno@borobudur.ac.id $\left.{ }^{2}\right\}$
}

\begin{abstract}
Human trafficking is quite complicated because there is still a lot going on in the world. The purpose of this research is to observe the politics of law in combating human smuggling. A transnational crime that places illegal immigrants and refugees from South Asia and the Middle East as material commodities, Indonesia has the potential for international crime. The researchers used in this study are normative legal research methods that are qualitative and mixed thinking logic (deductive and inductive). The study results are known to analyze problems related to a cross-border crime that hit the country so that the government needs to make a strategy to combat human smuggling.
\end{abstract}

Keywords: Political Law; Human Smuggling; Transnational Crime

\section{Introduction}

Indonesia is the fourth most populous country in the world and reached 274 million population in 2019 [1]. The density of Indonesia's population has not been accompanied by a projection of the demographic bonus that will occur in 2030. This high population density does not appear to be accompanied by the availability of adequate employment opportunities. Based on a survey from the Central Bureau of Statistic (BPS) in 2020 the unemployment rate in Indonesia reached 9.77 million people with a total workforce of 128.45 million people [2]. As a percentage, this number is indeed low. However, 9.77 million people are quite a high number. The three provinces with the highest open unemployment rates are DKI Jakarta, Banten, and West Java. These three provinces are highly populated. This unemployment can become a problem if it is not resolved early.

The existence of unemployment is closely related to the number of jobs. If jobs are widely available then unemployment will not exist. Struggle in finding a job leads to unemployment. The existing figures have not been added to the data on workers in the informal sector. The informal sector accounts for $60.47 \%$ of total employment. Based on BPS data, the 3 highest provinces with informal workers are Papua, NTB, and NTT [2]. Jobs in the informal sector are indeed included in the labor force, but in this field, there is almost no certainty such as health insurance, old age, and various other benefits. Jobs in this sector have more risks than in the formal sector.

Difficulty in accessing jobs and the absence of guarantees can lure the workforce to look for work elsewhere. Unemployment refers to poverty. In border areas between countries, poverty tends to make residents in that area look for work in other countries even though the path taken is not through formal channels so this can become an opening for human trafficking 
[3]. When residents are faced with economic problems, all means will be taken for them to meet their inviolable basic needs [4]. One bitter condition is that most of the victims of human trafficking are women and children.

Women and children are the weak and powerless parties in society. Especially in Indonesia, gender inequality is still quite high [5]. Even if there are cases involving women, it is not uncommon for it to be underestimated and the women are to blame. Women and children should receive equal treatment before the law and their rights are protected [6]. However, violence against women sometimes even occurs starting from the family environment.

Considering that the phenomenon of human trafficking occurs mostly at borders between countries and the victims are the majority of women and child workers, it is only natural for the government to protect its workers. Protection of workers is implemented by the government through the Law on the Placement and Protection of Indonesian Workers Abroad, namely Law Number 39 of 2004 [7]. However, the question that arises is whether the law is sufficient to protect Indonesian workers abroad and how is Indonesian politics in addressing human trafficking between countries? For this reason, this research will examine Indonesian politics and law in dealing with cross-border human trafficking.

\section{Method}

This study uses a qualitative approach by mixed mindset, namely deductive and inductive. In this study, the researcher provides a conclusion that is universal and profound by using the legal normative analysis method. While the data analyzed was taken from articles, research data, and various studies on facts in Indonesia. All existing data will be analyzed to obtain an overview of the existing research problems.

\section{Discussion}

\subsection{Human Trafficking}

Human trafficking is all actions taken to exploit or cause people to be exploited either by violence, fraud, forgery, imprisonment, or other similar actions [8]. Human trafficking mostly is in the form of migrant workers and also commercial sex workers. This is, of course, an illegal act against the law. Migrant workers are mere targets of human trafficking because most of them are unable to show or provide legal evidence that they are qualified to work as skilled workers overseas.

Most cases of human trafficking that occur are in the form of Indonesian workers who work abroad. Some of these workers become casual laborers in oil palm plantations, some become household assistants, and even become prostitutes [9]. The victims are usually people living in a hinterland between countries. They are lured to get a job with a high salary so that the victims are like buffaloes who are whipped by their noses to just follow the perpetrators who will sell them.

The victim is tempted by the deceptive lure that makes them simply believed. When examined further, the poverty factor is the main driving force for victims willingly to become illegal workers [3]. Border areas are usually green land for various illegal activities such from drug trafficking to human trafficking [10]. This is because this area is far from the monitoring 
of the central government so that crime is rampant. However, when it comes to human trafficking, not all of the border residents are victims. Ironically, some residents even become sellers of their partners [9].

As a sphere that is far from the central government, the border area is certainly obliged to be safeguarded and controlled. Especially from crimes such as human trafficking, because humans should have the same rights. Moreover, Indonesia is a country based on Pancasila that upholds social justice for its citizens [11]. Prevention of human trafficking in Indonesia in border areas is mostly done after cases occur. Pre-caution is rarely done, especially in the form of socialization. Human trafficking has started since these workers began to depart [12]. For this reason, adequate socialization needs to be the attention of the government. Especially besides the rampant cases of human trafficking in the form of illegal labor. These workers are deprived of their human rights both in terms of wages, welfare, and often their honor. It will be a critical stigma for Indonesia because there may thoughts that the Indonesian people can be used as a trading asset. Where in the present, slavery should be abolished, but it is still running around Indonesia.

Even though the border area is far from the center of government, the government needs to continue monitoring, it could be that there is a large potential natural resource. For example in the Merauke is the farthest in Indonesia, but this area has a large variety of potential both natural and non-natural such as livestock and plantations [13]. However, this kind of area is sometimes still far from being guarded. The role of local government is still not strong. The number of survivors between countries without permission from Merauke district to Papua New Guinea. This not only overrides state sovereignty but also creates opportunities for human trafficking.

In exploring the boundaries, the government has made various efforts. For example, in guarding the borders of Indonesia and Malaysia, there is a concept of a formal legal approach to defense that is adapted to the conditions of the place [14]. However, constraints still occur, the obstacles that appear include infrastructure, too large an area, and various other existing constraints. For this reason, a special study is required in conducting safeguards between countries. This study requires thorough preparation. It is because if the territories between countries can be controlled, then human trafficking will decrease. Tight supervision will reduce human trafficking. The education that is promoted will serve as a socialization function for the people in the area.

\subsection{Human Trafficking Law and Protection}

Indonesia has laws and protections for human trafficking, especially for migrant workers in other countries. The Preamble to the 1945 Constitution stated that slavery in the world must be eliminated, it is indicated that any work that does not fulfill the rights of workers and there is a compulsion in it must be abolished. Pancasila clearly states social justice for all Indonesian people [11]. As the source of all sources of law in Indonesia, Pancasila is, of course, the basis of all existing laws and regulations [15]-[19]. Ideologically, Indonesia rejects the existence of injustice towards workers in the form of coercion and the absence of rights that are given. In human trafficking, humans are treated as an asset that is not even humanized. It is very contradictory to the basic ideology of Indonesia which upholds social justice and equal rights for every citizen.

In the practice of human trafficking, women and children are more likely to be victims. Most victims, women, and children should obtain legal protection. The Constitution of the Republic of Indonesia 1945 article 28 B paragraph 2 states about the freedom and protection 
of children [20]. This legislation is the basis for child protection in Indonesia. Meanwhile, for migrant workers, the law that protects is Law Number 39 of 2004 concerning the Placement of Labor Abroad and its Protection. The law on the protection of women is based on Article 27 of the Constitution 1945 of the Republic of Indonesia which states the equal rights of every citizen. During this period of reform legislation issued to protect women's rights was considered quite progressive [21]. if there is an action that violates the rights of women is a violation of the laws and has been set by the government. Existing child protection laws have been designed to protect children from human trafficking. As a derivative of the 1945 Constitution article 28 b, the government issued Law Number 23 of 2002 on Child Protection [22]. The laws and regulations issued by the government for child protection are considered quite adequate [23]. From the laws and regulations issued by the government to protect the rights of children and women, the government's efforts in the field of legalization are sufficient.

In terms of eradicating human trafficking, the government issued Law number 21 of 2007 concerning the crime of human trafficking [24]. Based on the year that the Law was issued, it was only issued post-reform, which means that before the reformation there were almost no regulations to undertake human trafficking. It shows that statutory regulations continue to evolve in line with the times, especially in the era of disruption [25]. With the development of existing laws and regulations, it is expected to facilitate every problem and need of the Indonesian people. However, this development is also oriented towards Pancasila as the source of all existing sources of law.

\subsection{Human Trafficking Countermeasure}

Apart from the constitutional sector by issuing several laws and regulations to protect workers, women, and children in acts of human trafficking, the government also takes various countermeasures. Various efforts made by the government by educating, tightening the legalization of requirements for the exit of Indonesian workers, and other foreign policies so far have yielded results in the awareness of the importance of protecting Indonesian workers abroad. However, this result is still not significant because the source of the problem of human trafficking, namely poverty, is still unsolved [26]. If the source of the problem of human trafficking which is poverty can be resolved, the problem of human trafficking will also be significantly reduced.

Another attempt made by the Indonesian government is to undertake bilateral cooperation with several neighboring countries. For example, one of the collaborations carries out with Malaysia. The cooperation between the Indonesian and Malaysian police is expected to have a significant impact on human trafficking, especially in border areas. However, Saleh's research (2018) states that this collaboration has not produced significant results in reducing the amount of human trafficking [27]. Although it has not shown significant results in reducing human trafficking, at least this cooperation can minimize the occurrence of human trafficking on a larger scale. If the cooperation carried out can be developed continuously, it will be able to produce significant results in the end. In another study, Utami (2017) shows that the government's efforts to tackle human trafficking in Batam are still ineffective [28]. The ineffectiveness of government efforts is due to the lack of comprehensive cooperation between government agencies. This suggests that Indonesia's internal domestic factors are still far from the minimum standard to be able to deal with these trafficking acts.

Human trafficking, which is a crime that robs others' rights, is a violation. This action can be categorized into a criminal act, therefore, the perpetrators of human trafficking can be 
charged with criminal law [29]. Thus, the perpetrator cannot roam freely because of his actions. These perpetrators will be held accountable for their actions before the law so that it will also be a deterrent effect for other perpetrators. Meanwhile, victims of human trafficking will get all their rights. The rights of victims are based on Law number 21 of 2007, which includes the right to the confidentiality of the identity, rehabilitation of social, health, mental, and other conditions as well as economic compensation [30]. Besides that, restitution for the victim is also guaranteed to his heirs if something happens to the victim [31]. In his analysis, Fikriyanto (2020) states that so far, criminal acts against traffickers in human beings are still not being carried out optimally. This has resulted in the perpetrators still being caught under the existing laws and regulations. This fact will be tragic because the perpetrators who have taken away the rights of the victims can still wander freely while the victims have been deprived of their rights and it may difficult to return to society due to the shame and psychological trauma that the victims experienced. For this reason, the government needs to take further significant actions.

Observing the cases of human trafficking that are so prevalent, the government has taken various actions to combat it. At the juridical level, the government has issued various laws and regulations to ensnare the perpetrators of the criminal act of trafficking in persons. Not only that, regulations to protect workers and victims were also issued as a form of countermeasures. There are at least two steps taken by the government in dealing with the increasingly widespread act of trafficking in persons. Countermeasures and prevention [32]. Countermeasures are to carry out criminal law for the perpetrators of human trafficking. Meanwhile, prevention is to carry out various education and outreach to the public and workers so that the community has the correct knowledge of human trafficking, and is expected to reduce this behavior. While these actions are being taken, the government will continue to alleviate poverty, especially in areas that are vulnerable to human trafficking. This action clarified the government's political position in dealing with human trade. This position actually according to the laws and regulations is to strongly refuse. However, if it still happens, the practice could be influenced by personal actions that are outside the government's line.

\section{Conclusion}

Human trafficking is a cruel act that robs others' rights. This action is carried out in an organized manner for enriching oneself but harming others. Therefore this action must be eradicated. The Indonesian government has issued various laws and regulations to ensnare the perpetrators of the criminal act of human trafficking. On the other hand, the government has also issued laws and regulations to protect victims and provide restitution to them and their heirs. Bilateral and international cooperation is done to reduce the crime of human trafficking. Although the results have not been significant, in this regard it can be seen that the government's position is clear, namely to prohibit human trafficking.

The suggestion that can be given is that the government can further encourage academics in implementing social mapping to solve the root cause of human trafficking in Indonesia. Besides that, poverty alleviation can also be the key to solving this problem. On the other hand, the role of religious and cultural leaders is also needed to assist the government in alleviating the problem of human trafficking in Indonesia. This research is still in the form of a descriptive study of the article literature only, for that in further it is necessary to identify the factors that influence human trafficking in Indonesia. 


\section{References}

[1] D. H. Jayani, "2020, Indonesia's Fourth-Largest Population in the World," 2019. https://databoks.katadata.co.id/datapublish/2019/12/16/2020-penduduk-indonesiaterbesar-keempat-dunia.

[2] Sub-directorate of Statistical Analysis, National Employment Survey. Jakarta: BPSStatistics Indonesia, 2020.

[3] N. Niko, "Poverty as a Cause of Human Trafficking Practices in the Border Area of Jagoi Babang (Indonesia-Malaysia), West Kalimantan," Pros. Semin. Nas. INDOCOMPAC, pp. 515-524, 2016, [Online]. Available: http://jurnal.bakrie.ac.id/index.php/INDOCOMPAC/article/view/1625.

[4] P. A. Ginting, P. Beauty, K. Environment, and P. G. Women, "The Implementation of Maslow's Theory and the Dual Role of K3L Female Workers at Universitas Padajajaran," vol. 1, pp. 220-233, 2018.

[5] Sub-directorate of Statistical Analysis, Study of Gender Inequality Index Measurement. Jakarta: BPS-Statistics Indonesia, 2020.

[6] I. R. Sumirat, "Legal Protection of Women and Children Victims of Human Trafficking Crime," J. Stud. Gend. and Children, pp. 19-30, 2017, [Online]. Available: http://jurnal.uinbanten.ac.id/index.php/jsga/article/view/174.

[7] LAW OF THE REPUBLIC OF INDONESIA NUMBER 39 OF 2004 CONCERNING PLACEMENT AND PROTECTION OF INDONESIAN MANPOWER ABROAD, no. 2. Indonesia, 2004, p. 55.

[8] Sakroni, "Trafficking in Person, An Overview of the Social Aspects of Trafficking of Women and Children," Ilm. Worker. Sos., Vol. 11, no. 1, pp. 1-12, 2012.

[9] N. Niko, "The Phenomenon of Trafficking in Person in the Border Area of West Kalimantan," Raheema, vol. 4, no. 1, pp. 32-45, 2017, [Online]. Available: http://jurnaliainpontianak.or.id/index.php/raheema/article/view/829.

[10] V. Pusvitasary, "Illegal Economic Activities at the Border of Indonesia-Timor Leste," Westphalia, vol. 16, pp. 115-130, 2017.

[11] F. I. Febriansyah, "Justice based on Pancasila as a philosophical and ideological basis for the nation," DiH J. Ilmu Huk., Vol. 13, no. 25, p. 1, 2017, doi: 10.30996 / dih.v13i25.1545.

[12] T. Marhaeni and P. Astuti, "Trafficking at the Entikong-Tebedu Border Post: Cases at the Border between Indonesia and Malaysia," Social Science Forum, vol. 45, no. 1, pp. 34-50, 2018, doi: 10.15294 / fis.v44i1.15546.

[13] D. Marwasta, "Assistance for Border Area Management in Indonesia: Lessons Learned from KKN PPM UGM in Border Areas," J. Pengabdi. Kpd. Masy. (Indonesian J. Community Engag., Vol. 1, no. 2, pp. 204-216, 2016, doi: 10.22146 / jpkm.10607.

[14] M. Haris Zulkarnain and K. Roisah, "Defense Management Policy and the Impact of Its Policy on the Indonesian Malaysian Border," J. Magister Huk. Udayana (Udayana Master Law Journal), vol. 7, no. 4, p. 490, 2018, doi: 10.24843 / jmhu.2018.v07.i04.p06.

[15] C. M. Indah Susilowati, "Pancasila as the Source of All Sources of Law and Violence in the Name of Religion in Indonesia," Masal. Huk., Vol. 45, no. 2, p. 93, 2016, doi: 10.14710 / mmh.45.2.2016.93-100.

[16] D. P. Rahayu, "THE ACTUALIZATION OF PANCASILA AS THE BASIS OF 
INDONESIAN LEGAL POLITICS Derita," Yustisia, vol. 4, no. 1, pp. 190-202, 2015.

[17] F. Y. Bo'a, "Pancasila as a Source of Law in the National Legal System," J. Constitution, vol. 15, no. 1, pp. 27-49, 2018.

[18] A. Kumantiyorini, "Pancasila as the Source of All Sources of Law," Masal. - Massive. Huk., Vol. 45, no. 2, 2016.

[19] A. Arfa'i, B. J. Nasution, and F. Febrian, "The Actualization of Pancasila as a Source of Law in the Formation of Laws," Hukum J. Huk., Vol. 3, no. 2, pp. 377-407, 2020, doi: 10.22437 / ujh.3.2.377-407.

[20] Indonesian Constitution. Jakarta, Indonesia, 1945.

[21] D. Kania, "The Rights of Women in Indonesian Laws and Regulations," J. Constitution, vol. 12, no. 4, pp. 716-734, 2015.

[22] Law Number 23 of 2002 concerning Child Protection. 2002.

[23] A. K. Ayu, "The Effectiveness of Child Protection Law concerning Legal Protection of Child Victims of Human Trafficking in Indonesia," Lex Soc., Vol. 3, no. 1, 2015.

[24] Law Number 21 of 2007 concerning the Eradication of the Crime of Trafficking in Persons. 2007.

[25] S. Octavianus, "The Cultivation of Indonesia's Education Financing Policy in Disruption Era," Int. J. Adv. Soc. Econ., Vol. 1, no. 1, p. 16, 2019, doi: 10.33122 / ijase.v1i1.36.

[26] G. Wuryandari, "Examining Indonesian Foreign Policy in Addressing Human Trade Issues," Political ejournal. LIPI, vol. 8, pp. 213-227, 2010.

[27] D. W. Saleh, "Cooperation between Indonesia and Malaysia through the Joint Police Cooperation Committee (Jpcc) to Address Human Trafficking in Border Problems (2007-2017)," 2018.

[28] P. Utami, "THE INDONESIAN GOVERNMENT'S EFFORTS IN OVERCOMING HUMAN TRAFFICKING IN BATAM," eJournal ILmu Hub. Int., Vol. 5, no. 4, pp. 1257-1272, 2017.

[29] B. S. Daud and E. Sopoyono, "Application of Criminal Sanctions Against Human Trafficking in Indonesia," J. Pembang. Huk. Indonesia., Vol. 1, no. 3, pp. 352-365, 2019, doi: 10.14710 / jphi.v1i3.352-365.

[30] A. R. H. Putri and R. Arifin, "Legal Protection for Victims of Human Trafficking Crimes in Indonesia," Res Judicata, vol. 2, no. 1, p. 170, 2019, doi: 10.29406 / rj.v2i1.1340.

[31] Fikriyanto, "Juridical Analysis of the Crime of Human Trafficking concerning the Sending of Indonesian Workers Abroad BY INDIVIDUALS BASED ON LAW NUMBER 21 OF 2007 CONCERNING THE ERADICATION OF CRIMINAL ACTION OF TRAFFICKING IN PERSON," JDinamika, J. Ilm. Huk., Vol. 26, no. 9, pp. 1464-1477, 2020.

[32] A. Jamilah and N. J. P. Union, "Combating the Crime of Trafficking in Persons from a Criminal Political Perspective,” Justitia J. Huk., Vol. 4, no. 1, 2020. 